Mikuła Bogusz,

Associate Professor dr. hab., Cracow University of Economics, Kraków, Poland

ORCID: 0000-0002-5378-9768

\title{
KNOWLEDGE TRANSFER IN A BUSINESS ECOSYSTEM
}

The paper presents complex problems related to knowledge transfer for the purpose of the common use of knowledge resources by entities operating in a business ecosystem. A company's business ecosystem is understood as entities operating in its immediate environment, which share the same cooperation objectives and focus on delivering products, services or processes, for example innovative processes. The further part of the paper discusses the theoretical foundations of knowledge transfer in the context of knowledge transfer theories, as well as the characteristics and conditions of knowledge transfer in a business ecosystem, with consideration given to knowledge commercialization, knowledge transfer barriers, and selected knowledge transfer methods which can play a significant role in this process within the framework of a business ecosystem. The presented considerations lead to several practical conclusions for company executives and knowledge transfer experts.

Keywords: knowledge management, knowledge transfer, business ecosystem, knowledge transfer methods.

\section{Мікула Богуш. Передача знань у бізнес-екосистемі.}

У роботі представлено комплекс проблем, пов'язаних з передачею знань з метою загального використання ресурсу знань суб'єктами, що праџюють в бізнес-екосистемі. Під бізнес-екосистемою компанії розуміють суб'єкти, що діють у ї̈ безпосередньому середовищі, які поділяють ті самі ијілі співпраці та зосереджені на постачанні продуктів, послуг чи процесів, наприклад інноваційних прочесів. У статті розглядаються теоретичні основи передачі знань у контексті теорій передачі знань, а також характеристики та умови передачі знань у бізнес-екосистемі з урахуванням комериіалізачії знань, бар'єрів для передачі знань та обраних методів передачі, які можуть відігравати значну роль у иьому прочесі в рамках бізнес-екосистеми. За результатами дослідження надано декілька практичних висновків для керівників компаній та експертів з передачі знань.

Ключові слова: управління знаннями, передача знань, бізнес-екосистема методи передачі знань. 


\section{Introduction}

The knowledge economy offers unique opportunities for business activities, creating specific conditions and challenges for state institutions. Unfortunately, daily routine activities including customer acquisition efforts, counteracting unfair competition, raising funds for financing and developing economic activities etc. prevent managers from thinking about the future of their business operations. Executives should also focus on the context of economic activities, enabling them to make the right strategic decisions. The contemporary conditions created by the knowledge economy are rightly described by Z. Fan, B. Feng \& Z. Yu (2007), recommending specific activities in response to the existing situation:

1. Global economic integration. The development of global economic integration leads to greater interdependence between enterprises, and their mutual competition is transformed into competition between value chains, groups of companies and ecosystems.

2. The rapid development of information systems. The rapid development of modern information technology networks enables companies to benefit from computer networks, facilitating the process of combining activities related to product design, engineering, production, procurement, marketing and sales, and thus creating a global network of knowledge. Network information technologies enable companies to transfer their valuable knowledge resources to easily accessible and controllable platforms, and relevant knowledge and information can be effectively acquired, processed, transferred and applied thanks to cooperation between companies.

3. Knowledge becomes to be a company's most valuable asset. In the era of the knowledge economy knowledge and information are the main sources of value added, and innovation is the core of corporate activities. In order to increase the pace and effectiveness of innovative processes, companies must strengthen knowledge exchange and mutual interactions through cooperation methods, and integrate knowledge through creating links between knowledge resources.

4. There are gaps in companies' knowledge. When businesses face rapid and large-scale innovative activities in complex networks, they often demonstrate gaps in their knowledge resources. In order to close knowledge gaps, it is necessary to choose dynamic alliances or establish virtual companies with a view to carrying out innovative activities based on knowledge. Knowledge-based cooperation can lead to fast knowledge transfers and the effective sharing of knowledge, and a company's knowledge resources can be enlarged as a result of knowledge absorption.

5. The market requires companies to be responsive. A dynamic and changing market environment requires businesses to be responsive, and this, in turn, necessitates the fast and coherent transfer of knowledge. Therefore, companies should accelerate knowledge transfers in the network of processes through a coordinated approach, and conduct fast and thorough assessments of market changes, as well as shorten product launching processes. 
The development of cooperation aimed to share tangible and intangible assets is indispensable to innovation and corporate expansion. However, the Polish economy is lagging behind in this area. In the ranking of innovative systems in EU member states (European Innovation Scoreboard 2018) Poland takes 26th spot among 28 countries, representing $14^{\text {th }}$ spot (among 17 countries) below EU average. Simultaneously, it is classified as a country characterised by a moderate level of innovativeness. EU innovation processes record a 5.8 percentage point increase in 2010-2017 - the results are better in 18 member states and deteriorate in 10 countries. The result in Poland increases by $3.2 \%$, which is not satisfactory from the perspective of the innovativeness of the Polish economy and its efforts aimed to catch up with world trends and competitors. Ukraine's economy is not in good shape (Mazaraki \& Melnik 2013) and requires changes.

One of the possible ways to change the situation is the transformation of attitudes to cooperation between companies and giving due attention to their functioning within business ecosystems. The spectacular benefit of this approach is the fact that business ecosystem participants establish relationships aimed to exchange and use knowledge made available by ecosystems (Tereszko \& Pec 2018).

The objective of this work is to present a complex issue of knowledge transfer between business ecosystem entities. The achievement of this objective requires the explanation of the business ecosystem concept, an analysis of the theoretical foundations of knowledge transfer in the context of knowledge management theory, the identification of the characteristics and conditions of knowledge transfer in a business ecosystem in the context of knowledge commercialization and barriers to knowledge transfer, and the description of the knowledge transfer methods which are of key significance in implementing this process within the framework of a business ecosystem. The presented considerations lead to several practical conclusions for managerial staff and knowledge transfer specialists. The achievement of the above objectives is based on such research methods as literature review and deductive inference.

\section{The concept of a business ecosystem}

The term «business ecosystem» was used for the first time by J. F. Moore in 1993 (Abbate, Accordino, La Rocca \& Rupo 2017). This concept allows for gaining a different perspective in a research process for analysing and assessing the development and conditions of companies' operations as compared with an approach to enterprises operating in a traditionally understood environment or as components of a sector regarded as a value chain.

J. F. Moore states that «a business ecosystem» and its plural form «business ecosystems» refer to an intentional society of economic actors whose individual business activities have a major impact on the life of the entire society. The manufacturers of accessories for an innovative product can be treated as members of the business society of this product, or, in other words, members of this product's 
ecosystem. A business ecosystem can be also understood as a network of interdependent niches which are occupied by organizations. Such niches are, in varying degrees, open to alternative collaborators (Moore 2016). S. A. Zahra and S. Nambisan refer to a business ecosystem as a group of firms, and possibly other entities including natural persons, which cooperate within a system of interdependencies, manufacturing goods, technologies and offering services required by customers (Zahra \& Nambisan 2012). A company's ecosystem is composed of entities operating in its immediate environment, directly linked by cooperation relations, focused on a product, service or process, for example an innovative one. Apart from having common objectives, they compete, on a limited scale, which results from their entrepreneurship (Mikuła 2018). An advantage of being part of a business ecosystem results, among others, from the fact that such a system creates value for its participants who do not have expertise to independently commercialise a product or a service (Niemczyk \& Stańczyk-Hugiet 2014). Therefore, operating within a business ecosystem can be of special significance for startups.

The concept of a business ecosystem is an extension of the theory of value chain networks, which incorporates into value chains such organizations as universities, industry and stakeholder organizations along with their mutual interactions (Stańczyk-Hugiet 2015). Research studies of business ecosystems broaden the knowledge of complex interactions between such entities as pioneer entrepreneurs, formal and informal networks, infrastructure, venture capital, public aid for businesses based on various incentives, and research universities (Abbate, Accordino, La Rocca \& Rupo 2017).

\section{Knowledge transfer processes}

The concept of knowledge management is diversified in terms of the ways of defining knowledge, types of knowledge, understanding of knowledge management, the typology of knowledge-related processes (operational processes), and the descriptions of the knowledge management system. F. Gao, M. Li, S. Clarke, in their analysis of the definitions of knowledge offered by management literatures, point out that the currently cited definitions refer to such ideas as data, information, intelligence, skills, experience, expertise, ideas, intuition or insights (Gao, Li \& Clarke 2008). However, from the perspective of the idea of knowledge transfer it is crucial whether the concept adopted in practice is founded on the assumption that knowledge is an inherent element of human nature and mind and as such untransferable, or that knowledge is assumed to exist outside human mind and is subject to transfers. For example, the former assumption is the basis of the Japanese concept of knowledge management. The Japanese define knowledge as a proven conviction. It refers to beliefs and expectations. It is the function of a specific attitude, perspective or intentions, and it relates to actions. It is dependent on a context and is relative in character. On the other hand, information treated as flows of information is an instrument for discovering and building knowledge (Nonaka \& Takeuchi 2000). 
Information is transformed into knowledge when in the process of interpretation it provides a context and anchors in people's beliefs and commitments (Nonaka, Toyama, \& Konno 2000). In this approach, then, knowledge transfer does not practically occur, but knowledge is transmitted through information flows. Information is a knowledge carrier, but it is assumed that people acquire knowledge and communicate it (make it available) to others.

The Japanese believe that knowledge is «tacit» (hidden) - personal, contextual and difficult to transfer to another person, not to mention communication by means of computers. On the other hand, the people of the West tend to see knowledge as «explicit» - formal, unbiased and not so difficult to be transferred by means of computers (Nonaka, Umemoto \& Senoo 1996). The Western concept of knowledge management assumes that knowledge is built by means of data and information. If data and information are the components of knowledge, then their transfer can be treated as knowledge transfer.

These two approaches can be reconciled on the assumption that knowledge is «a flexible, dynamic and intangible «substance», the effect of the mental processing of sets of information possessed and acquired by humans» (Mikuła \& Pietruszka 2001), and also that three forms of knowledge can be distinguished (Krakowiak-Bal, Łukasik, Mikuła, Pietruszka-Ortyl \& Ziemiańczyk 2017): personalised knowledge, codified knowledge and well-grounded knowledge. Personalised knowledge belongs to humans. It can be divided into explicit and tacit knowledge. Explicit knowledge is non-contextual, and it can be codified by means of a formal and systemic language. It can be expressed by words (language) or mathematical formula, procedures and rules. Explicit knowledge can be easily communicated. Tacit knowledge, on the other hand, is personal, specific and dependent on a context. This type of knowledge is acquired through experience and practice. Therefore, it is difficult to formally describe, codify and communicate tacit knowledge (Sivakumar 2006). Codified knowledge indicates knowledge personalised in the process of codification. It is recorded on various types of carriers - it can be included in various types of documents (statutes, regulations, instructions, strategic plans, projects, publications, data bases, written agreements, special purpose letters etc.). Well-grounded knowledge results from the placement of personalised knowledge in the effects of human activity - products, services, systems, processes, technologies, brands, relationships or physical models (Krakowiak-Bal, Łukasik, Mikuła, Pietruszka-Ortyl \& Ziemiańczyk 2017).

Personalised knowledge is transferred in information and communication processes between humans, but knowledge transfer can also take place between a human and a machine. Codified knowledge can be transferred physically (through the transfer of its carrier - a document or disc) or electronically (by means of computer networks or wireless devices - radio signals or mobile telephony). The transfer of well-grounded knowledge depends on the form of the object in which knowledge is 
placed. If the object has a physical form (e.g. a product), transfer is effected through transport. If it has a different form (e.g. a technology, process, service or relationship), this type of knowledge can be transferred if it is transformed into a personalised or codified form, and then its original form is retrieved by the recipient.

Knowledge transfer is usually defined in terms of a process and treated as a process which comprises the knowledge which is a basis for organizational learning during which explicit or tacit knowledge is exchanged between at least two entities (Pietruszka-Ortyl 2018). M. Zięba describes knowledge transfer as a movement of knowledge from one place to another, from one person to another, from one organization to another, or from one organizational unit to another (Zięba 2018). Therefore, it can be assumed that knowledge transfer is a process during which personalised, codified or well-grounded knowledge is transferred (Krakowiak-Bal, Łukasik, Mikuła, Pietruszka-Ortyl \& Ziemiańczyk 2017), or a process of the simultaneous transfer of various types of knowledge. This process can take the following forms:

1. Knowledge acquisition - a transfer of knowledge from an organization's environment to its internal structure, and also a process during which employees acquire knowledge from internal sources - their collaborators, documents, data bases and available books or journals. The acquisition of knowledge can also take the form of retrieving it from competitive products or benchmarking processes. Also, knowledge acquisition can be effected through trainings, conferences or symposia, or informally through interactions with other people. A significant source of knowledge is provided by the media, especially with regard to possible opportunities and threats.

2. Providing access to knowledge - this process is the opposite of knowledge acquisition - people communicate knowledge to their collaborators by means of conveying information, for example verbal instructions as to how to perform specific tasks, or an employee is granted access to data bases or documents. Providing access to knowledge is also a process of the flow of information from an organization to its environment. It can take the form of communicating advisors' messages to customers by phone, delivering products along with instruction manuals, sending technical documentation to service outlets, exchanging technical information with product suppliers and recipients, and selling licences. Also, an organization provides access to its knowledge by simply selling its products and services and implementing processes that can be analysed by the environment and its entities.

3. Knowledge dissemination - an extended form of providing access to knowledge, and the difference between the two lies in the range of flows. Namely, providing access to knowledge is a process which targets specific recipients, and knowledge can be protected so that it cannot be accessed by unauthorised persons (e.g. providing access to customer data bases to selected sales people). Knowledge dissemination, on the other hand, aims to provide universal access to a specific source 
of knowledge. Knowledge can be disseminated through advertising, website pages with information on companies and their products, descriptions of cases and best practices in textbooks or conference proceedings.

4. Knowledge sharing - mutual exchange of knowledge in the process of communication and cooperation. The process consists in exchanging personalised, explicit and tacit knowledge by means of face-to-face contacts, conversations and the performance of tasks during which people gain common experience. During this process people can be supported by codified knowledge (e.g. information included in an organization's documentation) and well-grounded knowledge (e.g. an analysis of faulty products).

\section{The specificity and conditions of knowledge transfer in a business ecosystem}

Knowledge in organizations is not distributed in a uniform manner. If expertise is not available at a given place and time of operations, it must be delivered in due time. Unequal knowledge distribution in an organization necessitates organizing and improving knowledge transfer processes (Zięba 2018). The same is true of business ecosystems. However, there are considerable differences between knowledge transfer management processes in organizations and ecosystems. Organizations' activities aimed to plan, organize and control main knowledge transfer processes centralised in one unit of the structure (e.g. a knowledge broker) can greatly facilitate knowledge transfer. They contribute to the implementation of a given knowledge strategy supported by specific knowledge management strategies (aimed to develop a knowledge management system, close knowledge gaps and create the environment's knowledge resources), as well as relevant implementation methods. On the other hand, a business ecosystem's influencing mechanisms have a limited impact on its participants, being replaced by cooperation-rivalry mechanisms. In centralised networks transfers can be steered by a central entity, but effective knowledge transfers can be hindered by the following factors: different economic interests, the need for reaching a compromise by network participants, the necessity of choosing specific knowledge transfer methods in compliance with diversified strategic goals, knowledge strategies, knowledge management competences, knowledge management systems, the use of IT, and the changeable character of relations and impact factors. In decentralised networks, which do not have a central entity, or in which several entities seek to integrate and dominate the network, organizing a well thought-through knowledge transfer system can be hardly possible. Activities, in the natural order of things, are reduced to individual initiatives undertaken by particular pairs or small groups of business ecosystem participants.

It should be stressed that the empirical research confirms the correlation between an organization's absorptive capacity and its (central) position in the network, which has a major and positive impact on a company's innovativeness and performance (Lis 2018). 
Knowledge transfer is a basis for knowledge commercialisation. Generally, knowledge commercialisation is a process of implementing discoveries or inventions. In this process, a discovery is reflected in its market or social application (Buchowski \& Strycharz 2013).

It is assumed that approx. 95\% of companies' new product launches are failures. Experts believe that this percentage could be much lower if organizations' research teams were supported by scientists (Makowiec 2017), hence the significant function performed by universities and research centres.

The basic university-related knowledge commercialization methods usually include the four following activities (Makowiec 2017):

1. Selling invention or technology licence rights to another entity (industry or capital investor).

2. Granting licences to an interested entity, granting user rights to an invention, technology or other forms of work.

3. A strategic alliance - a relationship between a firm and an institution (university) aimed to achieve a common objective.

4. Independent implementation through establishing a spin-off or spin-out activity which will act as an independent seller of products or services. In this case development and commercialization activities are undertaken by an interested party. Such businesses are frequently typical startups, which directly or indirectly cooperate with universities.

Knowledge transfer and commercialization between business ecosystem entities can be hindered, abandoned or limited by a number of factors. In Poland such factors include (Adamczyk 2018):

- lack of a long-term consistent strategy for cooperation among major actors: scientists, students, graduates, entrepreneurs, universities and business environment institutions. Activities undertaken by authorities at various state levels are fragmented, they lack cohesion and are not complementary in character, and they do not create a comprehensive support system;

- bureaucracy of universities which follow complex regulations hindering cooperation with enterprises;

- lack of qualifications of Polish scientists to cooperate with businesses;

- low efficiency of academic technology transfer centres;

- underdeveloped innovation market (a common problem in Europe), hindering the commercialization of scientific achievements through selling licences and patents (for which technology transfer centres are well prepared);

- work overload of research workers (teaching hours) and little time dedicated to cooperation with business. 
Each of the above factors constitutes a problem in itself. For example, the main barriers to effective technology and knowledge transfers with the use of technology and knowledge centres or knowledge transfer centres are as follows (Bill 2018):

1) lengthy processes of managing intellectual property in research centres,

2) insufficient knowledge of research workers about the principles and benefits of technology transfer,

3) lack of permanent sources of financing for technology and knowledge centres,

4) lack of qualified staff to meet new challenges,

5) centres are not inclined to act as partners in cooperating with business and academia.

The last two factors relate to insufficient financing. For example, the Academic Entrepreneurship Incubators in Poland face the shortage of funds for training their staff. As a result, employees have a sense of treating their positions as temporary work. They work under constant stress resulting from the need to adapt to repeated changes in the functioning of the Academic Entrepreneurship Incubators (Siemieniuk, Gardocki \& Siemieniuk 2019) resulting from frequent changes in legislation. Consequently, young, able and aspiring people find jobs in such organizations only to establish contacts and then look for lucrative positions in corporations or engage in startup activities.

In practice, a frequent barrier to knowledge transfers is the fear that innovations can be illegally transferred to other entities which will be the first to sell them on the market (Barańska-Fischer, Blażlak \& Szymanski 2016). Other barriers to effective knowledge transfers include the following:

- hidden objectives of cooperation aimed to transfer knowledge by one of business partners with a view to financial gains from the sales of obsolete or ineffective solutions (e.g. technologies, designs, products), gaining access to protected knowledge, takeover of employees etc.,

- fear of illegal activities carried out by cooperating partners,

- - limited possibilities of the use of advanced information and communication technologies, especially in the case of small entities (including startups),

- lack of time and funds for building partner relationships between the future participants of knowledge transfers, i.e. lack of activities aimed to build trust and foster the attitude of commitment to performed tasks,

- the knowledge transfer process is not well prepared (lack of preliminary agreements and adoption of cooperation and knowledge transfer principles),

- conflicting elements of the organizational culture of ecobusiness cooperating partners,

- lack of knowledge about knowledge transfer methods.

The description of specific barriers to knowledge transfer is presented in Table 1. 


\section{Barriers to knowledge transfer by selected criteria}

\begin{tabular}{|c|c|c|}
\hline Human barriers & Organizational barriers & Technical barriers \\
\hline $\begin{array}{l}\text { •selective perception } \\
\text { •erroneous interpretation of terms } \\
\text {-lack of ability to listen } \\
\text { •erroneous interpretation of ideas } \\
\text { •erroneous interpretation of non- } \\
\text { verbal messages } \\
\text {-lack of/knowledge asymmetry } \\
\text {-lack of understanding } \\
\text { •emotions } \\
\text { •lack of trust } \\
\text { •conservative way of thinking } \\
\text {-fear of the loss of position and } \\
\text { influence } \\
\text { •failure to understand benefits of } \\
\text { knowledge sharing } \\
\text {-fear of revealing weaknesses } \\
\text {-resistance to the use of } \\
\text { technological tools } \\
\text { •lack of habitual participation in } \\
\text { knowledge transfer } \\
\text { •unreliability of sources of } \\
\text { knowledge } \\
\text { •lack of interpersonal } \\
\text { communication skills } \\
\text { •lack of skills of organizing virtual } \\
\text { teams }\end{array}$ & $\begin{array}{l}\text { •motivating system is actually } \\
\text { demotivating - e.g. lack of } \\
\text { incentives to use software tools } \\
\text { •piecework forms of compensation } \\
\text { •segmentation-based } \\
\text { organizational culture } \\
\text { • inappropriate organizational } \\
\text { atmosphere for knowledge sharing } \\
\text { •organizational structure (when } \\
\text { more complex, it leads to } \\
\text { communication problems, reduces } \\
\text { employee empowerment, results in } \\
\text { strict division of labour and, } \\
\text { possibly, structural gaps between } \\
\text { knowledge transfer participants } \\
\text {-ineffective organization of } \\
\text { meetings } \\
\text { •lack of solutions for gathering } \\
\text { knowledge } \\
\text { •lack of solutions for knowledge } \\
\text { dissemination } \\
\text { •lack of organizational ability to } \\
\text { absorb knowledge } \\
\text { •lack of trainings in new } \\
\text { organizational and technical } \\
\text { solutions } \\
\text { •employee turnover } \\
\text { •disregard for the context of } \\
\text { transferred knowledge } \\
\text { •complexity of communicating } \\
\text { messages - distortion of } \\
\text { information } \\
\text { •inappropriate organization of } \\
\text { work space resulting in ineffective } \\
\text { knowledge sharing }\end{array}$ & $\begin{array}{l}\text { • information noise } \\
\text { •unfriendly user interface } \\
\text { - lack of compatibility of tools } \\
\text { used by knowledge transfer } \\
\text { participants } \\
\text { •lack of IT knowledge transfer } \\
\text { tools } \\
\text { •lack of trainings in new } \\
\text { technological solutions } \\
\text { - lack of technical facilities for } \\
\text { quick communication with } \\
\text { knowledge transfer partners (e.g. } \\
\text { lack of cell service, exceeded size } \\
\text { limits), } \\
\text { •e-mail limitations } \\
\text {-limited internet speed } \\
\text { •extranet is not available }\end{array}$ \\
\hline
\end{tabular}

Source: author's research based on (Prorok 2018).

\section{Knowledge transfer support methods in a business ecosystem}

Knowledge transfer support methods in a business ecosystem can be divided into methods which create proper transfer conditions and those directly related to knowledge transfer implementation. The first group comprises, for example, various types of strategic alliance (learning). The second type includes, for example, the debate method. 
The efficiency of knowledge transfer in business ecosystems relies heavily on the adaptation of transfer methods to the existing needs, conditions and resources. The possible methods include the following:

- common trainings for business ecosystem staff - training participants acquire knowledge, but they also learn to provide access to and share knowledge. Common trainings for the staff of various parts of an ecosystem provide opportunities for establishing contacts, building trust and creating informal relationships which can contribute to direct knowledge sharing outside the training framework. Transfers mainly relate to explicit knowledge;

- mutual visits and meetings attended by the participants of business ecosystems - informal rather than formal contacts. They do not require preparations, facilitate personal interactions, stimulate knowledge identification and sharing;

- common problem solving teams - initiated by various ecosystem entities for the purpose of solving current cooperation problems and undertaking others. After solving problems teams resume their activities (initiated by one of ecosystem entities) within new frameworks to deal with new threats or rectify errors in cooperation and performed tasks;

- Communities of Practice - a very effective knowledge transfer method. They represent groups of people who share ideas and thoughts and help one another in solving problems and developing common practices. They are of key significance in organizations based on interdisciplinary teams. Communities of Practice can be set up by groups of specialists who, in an informal way, share knowledge in unstructured discussions in which participants ask their colleagues to express their opinions on various issues or consult specialists from different business entities. Communities are the natural effects of people's inclination to seek companionship and cooperation, but they can also be set up to serve specific purposes (McDermott 1999). Communities of Practice can contribute to the transfer of explicit and tacit knowledge;

- Communities of Creation - they are set up when firms create customer groups for sharing expertise and encourage interactions for the purpose of generating new knowledge. Such groups work together for longer periods of time, sharing similar interests and willingness to create and share knowledge. Unlike in the case of traditional practices, such groups act beyond the frameworks of their organizations, creating value for various business entities (Paquette 2006);

- customer (consumer) communities - they provide access to the valuable knowledge about products, services and related problems, behaviours in the context of business transactions in communities, and information on the ways of entering into interactions (Rowley 2002);

- virtual teams - multifunctional structural solutions. They contribute to developing organizational networks (internal and external), and allow for increasing the number of project-dedicated people without changes in structures or the 
organization of work. Also, they facilitate a more effective use of employees (especially their knowledge), who can simultaneously engage in implementing several projects. Virtual teams can provide effective support for office-based teams and access to their knowledge, thereby supporting innovation processes. Finally, this form of work allows for engaging people who work from different geographic locations, which implies the use of the human capital that could not be benefited from using traditional employment solutions (Stefaniuk 2014). The key process that determines the work of a virtual team is knowledge transfer. It takes place inside the team, among its members, as well as between the team and its environment (Mikuła \& Stefaniuk 2013). The use of appropriate information and communication technologies enables the team to efficiently transfer knowledge as well as to implement other knowledge-related processes including knowledge creation. The use of virtual teams can enlarge the existing business ecosystem by supplementing it with new entities or their representatives;

- Knowledge Agents - this method consists in appointing a person or setting up an organization which stores, acquires, provides access to or uses knowledge resources. Knowledge agents exchange knowledge in specialised knowledge networks and - in the context of the ubiquitous character of information, communication and media technologies - in relations between organizations (Loebbecke \& Angehrn 2006). The tasks of knowledge agents can be performed, for example, by special entities appointed by local authorities for the purpose of supporting startups. Such entities transfer knowledge resources to economic entities with regard to such issues as the possible sources of financial support;

- Joint Intellectual Property - this formula enables firms to perform successfully over longer periods of time through educating customers, the common use of intellectual property and the continuous enlargement of knowledge. A firm and its partners jointly develop future business activities, analyse the scope of joint undertakings, initiate strategic projects and enlarge knowledge resources (Gibbert, Leibold \& Probst 2002).

The development of information technologies, the pace of which is unprecedented in history, is the dominant trend in the technological advancement of the recent decades. This trend is observed in world leading economies, resulting in the creation of the innovative information segment. Information technologies are the drivers of change in economic structures, and they have the potential to introduce qualitative changes in production processes, their organization and engaged labour resources (Mazaraki \& Duginets 2018). These factors cannot be disregarded in the analysis of knowledge transfer methods. A significant role in organizations is played by intranet in the field of sending data and information; equally significant tasks are performed by extranet in the network of enterprises and institutions in improving knowledge transfer processes. Extranet is a private network which can be accessed 
only by authorised entities. Therefore, it provides an appropriate protection of transferred knowledge, allowing for the creation and use of common knowledge resources.

The development of the internet, social media, dispersed data bases and various mobile devices results in a considerable increase in the amount of data. A great proportion of diversified data, in structured or unstructured forms, has a valuable business value, which, if properly used, constitutes a significant strategic resource. Such data comprises information on customers, competitors, labour markets and development trends for industries, products and services, as well as public and political sentiments. However, a number of organizations make a limited use of valuable and available data due to the lack of appropriate tools, or simply because of the failure to understand its significance (Olszak, Goyal \& Zurada 2019). In this context it is worthwhile to mention Business Intelligence - the software and set of tools enabling end users to screen and analyse data and business knowledge with the use of automatic analyses or human-computer interaction (Khan, Ganguly \& Gupta 2006). Business Intelligence standard systems integrate data from an organization's internal information systems and data from a specific environment, e.g. statistics, financial and investment portals as well as various data bases. Such systems are designed to provide reliable information on different aspects of an organization's activities (Olszak \& Ziemba 2007).

This brief review of knowledge transfer support methods in an ecosystem indicates that the implementation of any undertaking should be coupled with properly designed and frequent communication among knowledge transfer participants. Regular communication enables project workers to achieve high productivity levels. When regularly informed about project developments, they feel much more comfortable in performing their tasks. They must be provided with full information necessary to carry on with their work. Efficient and effective communication is a key success factor in any undertaking (Fragomeni \& Rizzo 2017).

Conclusion. The review of the presented considerations on knowledge transfer in ecosystems leads to the following conclusions:

- presently, ecosystems are network participants which should be considered not only by startups but all economic entities. They provide new insights into economic conditions, especially in the context of new opportunities for the use of knowledge resources;

- participation in a business ecosystem provides opportunities for increased competitiveness, especially through a combined use of resources belonging to the participants of a given network system;

- the participants of a business ecosystem must consciously create mutual relations for the purpose of strengthening cooperation aimed to use common knowledge resources, 
- the integration of an ecosystem's knowledge resources increases its performance potential and its ability to compete with the participating entities, attracting new members and providers of funds;

- the effectiveness of the knowledge transfer system in a business ecosystem is dependent on people's commitment, the conditions of implementation and the use of adopted methods including information technologies;

- it is necessary to support informal relationships among people working in a business ecosystem and the functioning of various communities engaged in achieving its objectives, as well as to seek openness in cooperating people's communication processes;

- building extranet networks between business ecosystem entities can improve knowledge transfer processes and increase the competitiveness of business ecosystems in their relations with external entities and other ecosystems;

- effective communication among business ecosystem entities eliminates the sense of hidden objectives in cooperation projects.

The above conclusions can be used as guiding principles for knowledge transfer managers and experts.

\section{REFERENCES}

1. Abbate, T., Accordino, P., La Rocca, E. T., \& Rupo, D. (2017, September). Intellectual capital and enabling factors for startups in a business ecosystem perspective, [in:] 10th Annual Conference of the EuroMed Academy of Business. (Eds.) D. Vrontis, Y. Weber \& E. Tsoukatos, Rome: EuroMed Press 37-52.

2. Adamczyk, M. (2018). Komercjalizacja technologii na przyktadzie na przyktadzie projektu KRK INNOTECH STARTER. In Wybrane problemy zarzadzania $w$ gospodarce opartej na wiedzy - przedsiębiorczość i zachowania innowacyjne.(Eds.) M. Makowiec, B. Mikuła \& A. Pietruszka-Ortyl.Kraków:Katedra Zachowań Organizacyjnych, Uniwersytet Ekonomiczny w Krakowie, 139-150 [in Polish].

3. Barańska-Fischer, M., Blażlak, R., \& Szymański, G. (2016). Innowacje w biznesie. Wybrane zagadnienia. Łódź: Wydawnictwo Politechniki Łódzkiej [in Polish].

4. Bill, R. (2018). Analiza konstruktu i ocena polskiego modelu innowacyjności opartego o transfer technologii $i$ wiedzy z jednostek naukowych do przedsiębiorstw, [in:] Wybrane problemy zarzadzania $w$ gospodarce opartej na wiedzy przedsiębiorczość i zachowania innowacyjne. (Eds.) M. Makowiec, B. Mikuła \& A. Pietruszka-Ortyl. Kraków: Katedra Zachowań Organizacyjnych, Uniwersytet Ekonomiczny w Krakowie, 17-30 [in Polish].

5. Buchowski, A., \& Strycharz, J. (2013). Innowacja i komercjalizacja a nauki społeczne. In Nauki społeczne a komercjalizacja wiedzy. Jak humaniści tworza 
innowacje dla gospodarki i społeczeństwa. (Ed.) S. Rudnicki. Kraków: Wyższa Szkoła Europejska [in Polish].

6. Fan, Z., Feng, B., \& Yu, Z. (2007). 知识协同的发展及研究展望 Retrieved from http://www.cicpa.org.cn/Column/hyxxhckzl/xxjsyqy/201708/W020170802479 131098668.pdf [in Chinese].

7. Gibbert, M., Leibold, M., \& Probst, G. (2002). Five styles of customer knowledge management, and how smart companies use them to create value. European management journal, 20(5), 459-469.

8. European Innovation Scoreboard 2018 (2018). Retrieved from https://ec.europa.eu/docsroom/ documents/33147

9. Fragomeni, F., \& Rizzo, R. (2017). The Effectiveness and Efficiency of Project Management Communication. In: Knowledge - Economy - Society. Management in the face of contemporary challenges and dilemmas. (Eds.) A. Jaki, \& B. Mikuła. Cracow: Publishing House: Cracow University of Economics, Faculty of Management, Foundation of the Cracow University of Economics.

10. Gao, F., Li, M., \& Clarke, S. (2008). Knowledge, management, and knowledge management in business operations. Journal of knowledge management, 12(2), 3-17.

11. Khan, S., Ganguly, A.R., \& Gupta A. (2006). Creating Knowledge for Business DecisionMaking. In: Encyclopedia of Knowledge Management. (Ed.) D. Schwartz. Hershey - London - Melbourne - Singapore: Idea Group Reference, 81-89.

12. Krakowiak-Bal, A., Łukasik, P., Mikuła, B., Pietruszka-Ortyl, A., \& Ziemiańczyk, U. (2017). Zarządzanie wiedza w rozwoju obszarów wiejskich. Warszawa: Wydawnictwo CH Beck [in Polish].

13. Lis, A. (2018). Rozwój badań naukowych w zakresie zdolności absorpcyjnej organizacji. Organizacja i Kierowanie, (3), 77-96 [in Polish].

14. Loebbecke, C., \& Angehrn, A. (2006). Coopetition. In: Encyclopedia of Knowledge Management. (Ed.) D. Schwartz. Hershey - London - Melbourne Singapore: Idea Group Reference, 58-66.

15. Makowiec, M. (2017). Start-upy technologiczne generujące innowacje w gospodarce jako efekt komercjalizacji badań naukowych. Nierówności społeczne a wzrost gospodarczy, (52), 424-441 [in Polish].

16. Mazaraki, A.A., \& Duginets, G. (2018). «Internet of Things» in the Global Production: Experience for Ukraine. In: Knowledge, Economy, Society: Reorientation and Transformations of Economy and Organization Management Concepts. (Eds.) B. Mikuła \& T. Rojek. Cracow: Cracow University of Economics, Faculty of Management, Foundation of the Cracow University of Economics.

17. Mazaraki, A., \& Melnik, T. (2013). Foreign-trade Sector of Ukrainian Economy. Visnyk Kyi'vs'kogo nacional'nogo torgovel'no-ekonomichnogo universytetu Herald of the Kyiv National University of Trade and Economics, 2, 5-15, (6), 5-27. 
18. McDermott, R. (1999). Nurturing three-dimensional communities of practice. Knowledge Management Review, 26-29. Retrieved from https://www.nickols.us/ Dimensions.pdf

19. Mikuła, B. (2018). Zarządzanie kapitatem ludzkim w ekosystemie biznesu z perspektywy start-upu. In Wybrane problemy zarzadzania $w$ gospodarce opartej na wiedzy - przedsiębiorczość i zachowania innowacyjne.(Eds.) M. Makowiec, B. Mikuła \& A. Pietruszka-Ortyl. Kraków:Katedra Zachowań Organizacyjnych, Uniwersytet Ekonomiczny w Krakowie, 83-102 [in Polish].

20. Mikuła, B. (2011), Transfer wiedzy $w$ organizacji. In: Komunikacja $w$ procesach zarządzania wiedza. (Ed.) A. Potocki. Kraków: Uniwersytet Ekonomiczny w Krakowie, Fundacja Uniwersytetu Ekonomicznego w Krakowie [in Polish].

21. Mikuła, B., \& Pietruszka, A. (2001). Zarządzanie wiedzą a sieci aliansów strategicznych. In Zarządzanie strategiczne. Stan i perspektywy rozwoju. (Ed.) R. Krupski. Wałbrzych: Komitet Nauk Organizacji i Zarządzania Polskiej Akademii Nauk oraz Wałbrzyska Wyższa Szkoła Zarządzania i Przedsiębiorczości, Wałbrzych [in Polish].

22. Mikuła, B., \& Stefaniuk, T. (2013), Zarządzanie wiedzą w zespole wirtualnym jako istotny czynnik jego skutecznej pracy, Zeszyty Naukowe Uniwersytetu Przyrodniczo-Humanistycznego w Siedlcach, 97, 109-124 [in Polish].

23. Moore, J. F. (2006). Business ecosystems and the view from the firm. The antitrust bulletin, 51(1), 31-75.

24. Niemczyk, J., \& Stańczyk-Hugiet, E. (2014). Klient w strategiach organizacji biznesowych. Nauki o Zarządzaniu, (2 (19)), 33-43 [in Polish].

25. Nonaka, I., Toyama, R., \& Konno, N. (2000). SECI, Ba and leadership: a unified model of dynamic knowledge creation. Long range planning, 33(1), 5-34.

26. Nonaka, I., \& Takeuchi, H. (2000). Kreowanie wiedzy $w$ organizacji. Warszawa: Poltext [in Polish].

27. Nonaka, I., Umemoto, K., \& Senoo, D. (1996). From information processing to knowledge creation: a paradigm shift in business management. Technology in society, 18(2), 203-218.

28. Olszak, C., Goyal, S., \& Zurada, J. (2019, January). Introduction to the Minitrack on Business Intelligence and Big Data for Innovative and Sustainable Development of Organizations. In Proceedings of the 52nd Hawaii International Conference on System Sciences, 125-126. Retrieved from https://scholarspace.manoa. hawaii.edu/bitstream/10125/60225/intro-3.pdf

29. Olszak, C. M., \& Ziemba, E. (2007). Approach to building and implementing business intelligence systems. Interdisciplinary Journal of Information, Knowledge, and Management, 2(1), 135-148.

30. Paquette, S. (2006). Customer Knowledge Management. In: Encyclopedia of Knowledge Management. (Ed.) D. Schwartz. Hershey - London - Melbourne Singapore: Idea Group Reference, 58-66. 
31. Pietruszka-Ortyl, A. (2018). The challenges of knowledge transfer in organizations in Poland - discussion on empirical study. Contemporary Issues in Economics, Business and Management. (Ed.) V. Babić.Kragujevac: Faculty of Economics University of Kragujevac, 39-48.

32. Prorok, M. (2018). Bariery transferu wiedzy w relacjach nauki z biznesem. In: Wybrane problemy zarzadzania w gospodarce opartej na wiedzy-przedsiębiorczość $i$ zachowania innowacyjne.(Eds.) M. Makowiec, B. Mikuła \& A. Pietruszka-Ortyl. Kraków: Katedra Zachowań Organizacyjnych, Uniwersytet Ekonomiczny w Krakowie, 219-230 [in Polish].

33. Rowley, J. (2002). Eight questions for customer knowledge management in e-business. Journal of knowledge management, 6(5), 500-511.

34. Siemieniuk, Ł., Gardocki, A., \& Siemieniuk, N. (2019). Fraktalne właściwości akademickich inkubatorów przedsiębiorczości (AIP). Optimum. Economic Studies, 3 (97), 92-105 [in Polish].

35. Sivakumar, S.C (2006). E-Learning for Knowledge Dissemination. In: Encyclopedia of Knowledge Management. (Ed.) D. Schwartz. Hershey - London Melbourne - Singapore: Idea Group Reference, 152-161.

36. Stańczyk-Hugiet, E. (2015). Strategicznie o ekosystemie biznesu. Prace Naukowe Wałbrzyskiej Wyższej Szkoły Zarządzania i Przedsiębiorczości, 32(2), 395409 [in Polish].

37. Stefaniuk, T. (2014). Komunikacja w zespole wirtualnym, Warszawa: Difin [in Polish].

38. Tereszko, W., \& Pec, M. (2018). Ekosystemy - nieskończone zasoby oparte na kapitale ludzkim. Studia i Prace WNEiZ US, (52 T. 3. Zarządzanie), 143-151 [in Polish].

39. Zahra, S. A., \& Nambisan, S. (2012). Entrepreneurship and strategic thinking in business ecosystems. Business horizons, 55(3), 219-229.

40. Zięba, M. (2018). Wiedza i jej przepływy w firmach oferujących wiedzochłonne usługi biznesowe. Monografie 177. Gdańsk: Politechnika Gdańska [in Polish].

The work co-financed by the fund for maintaining the research potential of the Faculty of Management of the Cracow University of Economics. 